\title{
FLORIANÓPOLIS: espaço urbano, poder público e disciplinarização - (décadas 1910 e 1920)
}

\author{
Sandro da Silveira Costa*
}

\section{Resumo}

Este artigo tem por objetivo discutir o aprimoramento do aparato legislativo implantado em Santa Catarina e em sua Capital, especialmente durante as décadas de 1910 e 1920, dispositivo este que pretendeu melhor organizar e controlar o deslocamento dos veículos - motorizados e/ou operados por força motriz animal - pelas vias intermunicipais e pelas ruas do perímetro urbano da cidade de Florianópolis. Analisamos, também, as percepções expressas pelos órgãos governamentais locais a respeito das tentativas colocadas em prática para prover o saneamento e a higienização do perímetro urbano da capital catarinense. Essas ações disciplinadoras objetivaram adequar este espaço às posturas civilizatórias propagadas pelas elites locais, observadas naquelas facções ligadas ao viés republicano que almejavam - pelo menos em teoria - o progresso material e moral da sociedade brasileira da época.

Palavras-chave: Disciplinarização. Condutas sociais. Municipalidade. Saneamento. Higienização.

No presente artigo, objetivamos tecer uma discussão sobre a evolução do aparato legislativo implantado no Estado de Santa Catarina e na cidade de Florianópolis, especialmente durante as décadas de 1910 e 1920; dispositivo este que pretendeu melhor organizar e controlar o deslocamento dos veículos - motorizados $^{1}$ e/ou operados por força motriz animal - pelas vias intermunicipais e pelas ruas do perímetro urbano da cidade de Florianópolis.

\footnotetext{
* Departamento de História, Centro de Filosofia e Ciências Humanas - UFSC, Campus Universitário, Florianópolis/SC. Email: sandrocosta31@brturbo.com.br.

${ }^{1}$ Neste artigo, o transporte motorizado é consubstanciado nos automóveis, os quais são movidos por motores acionados por combustão interna. Eles envolvem três categorias: a) automóveis particulares; b) automóveis de aluguel; e c) automóveis de praça. Os termos “carro”; “carroça”; "bonde” referenciados, também, no transcorrer deste artigo, referem-se aos veículos operados com tração animal.
} 
Diante desse quadro, devemos observar os seguintes questionamentos: Como o espaço público da capital catarinense foi gradualmente disciplinado - devendo-se considerar, naturalmente, os conflitos, embates e nuanças expressos pelos interventores da urbe (agentes detentores do saber e do poder de intervir, transformar e edificar a cidade segundo normas legais e jurídicas) e os usuários cotidianos da cidade (boleeiros, transeuntes, chauffeurs, passageiros $^{2}$ ), inerentes a esse processo - para acondicionar o tráfego de veículos operados por força motriz animal e, posteriormente, aquele representado pelos automóveis? Até que ponto as regras e as normas de trânsito implementadas na cidade de Florianópolis, especialmente a partir da década de 1920, apresentaram alterações e/ou adaptações frente às legislações que norteavam, pelo menos desde o final do século XIX, a circulação dos carros e carroças operados por força motriz animal, para, dentre outros objetivos, atender à circulação dos automóveis? Em que medida a legislação de trânsito aplicada no Estado de Santa Catarina e, especialmente, em sua Capital, atendeu, de maneira concomitante, à circulação automobilística e àquela operada por pedestres e veículos não motorizados? De que modo foram organizados os órgãos fiscalizadores do trânsito no âmbito da capital catarinense no período em estudo? Esses são, em síntese, os questionamentos que procuramos equacionar neste artigo.

\section{Passagens para Veículos}

Nesta seção, objetivamos analisar que, já durante a década de 1910, verificamos, entre os principais dispositivos da legislação estadual relativos ao trânsito, nítida preocupação quanto à circulação de veículos automotores e/ou operados por força motriz animal. No início da década de 20 do século passado, atestamos, no Estado de Santa Catarina, especialmente em Florianópolis, a implantação de algumas disposições e órgãos regulamentares de trânsito. $\mathrm{O}$ Regulamento para o serviço policial do Estado, instituído no ano de 1920, estipula, dentre outros dispositivos, que (Santa Catarina. Regulamento para o serviço policial do Estado, 1920) “[...] os condutores de veículos devem dispor da respectiva carta de habilitação” e apresentar “[...] idade igual ou superior a dezoito anos”.

Além desses elementos, o referido documento estabelece as obrigações comuns (Santa Catarina. Regulamento para o serviço policial do Estado, 1920) “a todos os cocheiros, carroceiros e motoristas”, pois eles devem trazer, estando em serviço, “[...] a carteira de

\footnotetext{
${ }^{2}$ Estes personagens correspondem, para os efeitos deste estudo, aos habitantes da cidade de Florianópolis.
} 
habilitação"; "guiar com prudência os animais, carros, bondes e automóveis ${ }^{3}$, para evitar prejuízos aos transeuntes e passageiros”; “caminhar nas ruas da cidade a trote curto, sem precipitar o ritmo de deslocamento dos animais e o movimento dos carros ou automóveis”; "manter acesas as lanternas, quando trafegarem no período noturno"; "guardar a ordem quanto às ruas de subida e de descida”; e "diminuir a marcha nas proximidades das esquinas para evitar choques ou encontros com outros veículos”. Analisando, especialmente, as obrigações comuns “a todos os cocheiros, carroceiros e motoristas”, observamos a determinação para que os condutores e motoristas estejam devidamente habilitados para a condução de veículos automotores ou tracionados por força motriz animal. Além disso, percebemos preocupações em prover-se segurança ao tráfego de transeuntes e passageiros. Outro elemento importante é o registro de que os condutores deveriam "guardar a ordem quanto às ruas de subida e descida”. Indicativos a respeito são expressos pelo artigo 136 do Regulamento para o serviço policial do Estado, que registra que (Santa Catarina. Regulamento para o serviço policial do Estado, 1920) “Art. 136 - Pela delegacia auxiliar serão expedidos editais designando as ruas de subida e descida [...]”.

Constatamos, portanto, que já havia, dentro do regulamento policial em questão, menções à expedição de normas que visavam a determinar quais os sentidos que os chauffeurs e boleeiros ${ }^{4}$ deveriam seguir ao guiar os veículos nas ruas da Capital. Esclarecemos que não nos foi possível encontrar os “editais” supracitados. Porém, fazemos, aqui, referência ao “Edital” datado de 18 de julho de 1927, expedido pelo então delegado de polícia do município de Florianópolis. Esse edital registra os locais permitidos para a prática e aprendizagem da condução de automóveis:

Edital - O tenente coronel Manoel Pereira da Silva e Oliveira, delegado de polícia do município de Florianópolis, encarregado do expediente da delegacia auxiliar, na forma da lei etc. Faz saber, aos que o presente edital virem ou dele conhecimento tiverem, que de conformidade com o artigo 129 do regulamento policial de 1920, é expressamente proibido guiar qualquer veículo sem estar para este habilitado com a respectiva carta expedida por esta delegacia auxiliar, bem como, ao condutor de veículo que confiar a direção de seu carro à pessoa que não tenham carta, sendo que as que

\footnotetext{
${ }^{3}$ É importante observarmos que, nessa passagem, a expressão “automóveis” é registrada posteriormente, pois os condutores devem guiar, em primeira mão, “os animais, carros e bondes [...]”. Isso sugere que, no ano de 1920, os automóveis ainda não dispunham de posição privilegiada frente aos demais veículos, ao circularem pelas ruas de Florianópolis; posição esta que conquistaram, de maneira progressiva, durante os anos seguintes.

${ }^{4}$ Para os efeitos deste estudo, os chauffeurs são aqueles que guiam os veículos automotores, enquanto os boleeiros e/ou cocheiros são aqueles que guiam os veículos tracionados por força motriz animal. Neste ponto, devemos esclarecer que na capital catarinense, a desativação completa do serviço de bondes ocorreu na década de 1930; e, durante todo o período em que esteve em atividade (pelo menos desde 1880 a 1935), este serviço foi operado por tração animal. Ver: a) DESTERRO. THIAGO, Polidoro Olavo de São. Ofício encaminhado ao Presidente da Província João Rodrigues Chaves. Desterro, 03 nov. 1880; b) Os bondes de Florianópolis. O Estado, Florianópolis, 10 jan., 1925, p. 5; e c) Um bonde destruído por populares. O Estado, Florianópolis, 26 set., 1934, p. 6.
} 
desejarem a aprendizagem poderão fazê-la com licença prévia desta delegacia, em logradouros públicos, como sejam: Largo 13 de Maio, Largo General Osório e Praça do distrito da Trindade, onde não causarão atropelo aos transeuntes; e isso com o condutor ao lado, ficando o mesmo responsável pela direção (PROCESSO 194, 1932, Caixa 20) ${ }^{5}$.

Esse mesmo edital (Processo 194, 1932, Caixa 20) "[...] foi publicado na mesma data, no jornal República, órgão oficial, para o devido conhecimento público, durante alguns dias e fixado no lugar de costume na Prefeitura Municipal, como é de praxe [...]”. Como observamos, era prática costumeira fixar editais dessa natureza na Prefeitura Municipal, e podemos perfeitamente inferir que os "editais" que designariam "as ruas de subida e descida”, registrados no artigo 136 do Regulamento para o serviço policial do Estado, foram, muito provavelmente, fixados, também, no local supracitado.

Artigos ou determinações expressas que estipulassem os sentidos de ida e vinda nas estradas e ruas estaduais, ou mesmo naquelas circunscritas ao perímetro urbano da capital catarinense, fizeram-se presentes, com maior nitidez, apenas quando da publicação das Instruções Regulamentares para o serviço de trânsito público, datadas do ano de 1928 - ver referências a esta legislação de trânsito nas páginas seguintes. Esse aspecto permite-nos considerar, uma vez mais, que o processo de introdução e de circulação dos veículos motorizados pelas ruas da Capital foi efetuado de maneira gradual.

Exigências semelhantes foram estipuladas pela Lei Estadual 1325, de 18 de agosto de 1920, pois registra que (Santa Catarina. Lei 1325, 1920, pp. 13-14) “Art. 1. ${ }^{\circ}$ - O exame de habilitação para os condutores de veículos, a que se refere o art. 113, do Regulamento para o serviço policial do Estado, será exigido somente das pessoas que conduzirem automóveis de uso particular ou de aluguel [...]”. Essa lei estipula no parágrafo primeiro desse artigo, que (Santa Catarina. Lei 1325, 1920, p. 13) “\# 1. ${ }^{\circ}$ - Os veículos de uso privado, exceto os automóveis, poderão ser dirigidos por condutores sem carta, desde que [...] tenham idade igual ou superior a dezoito anos [...]”"

\footnotetext{
${ }^{5} \mathrm{O}$ artigo aqui apresentado é uma reelaboração do segundo capítulo de minha tese de doutorado, intitulada Os Transportes Motorizados em Florianópolis: percepções e sensibilidades cotidianas (1920-1941), defendida no mês de março de 2010, junto ao programa de pós-graduação em História da Universidade Federal de Santa Catarina. Nesta tese, foram analisados processos criminais que contemplam episódios de atropelamentos e colisões no perímetro urbano da capital catarinense. A tônica geral que perpassa a análise desses documentos - e das demais fontes pesquisadas na tese - observa que a circulação dos automóveis se impôs gradativamente àquela operada por transeuntes e veículos não motorizados. Tal imposição foi processada de maneira gradativa no decorrer das décadas de 1910 e 1920, e devemos observar que os transeuntes, ao circularem pelas ruas do perímetro urbano da Capital, operam, muitas vezes, táticas e estratégias específicas, ditadas pelas condicionantes do viver urbano, que conferem caráter imprevisível e circunstancial às atitudes por eles tomadas para se esquivarem das investidas operadas pelos veículos motorizados. Além disso, é importante percebermos que os chauffeurs, condutores dos automóveis, operam, também, artifícios e recursos diversos para, muitas vezes, evitar atropelamentos e colisões.
} 
Ainda no início da década de 1920, foram implantados órgãos fiscalizadores do trânsito no Estado de Santa Catarina, conforme registra o artigo primeiro do Decreto Estadual 1465A de 17 de maio de 1921, que cria, anexa à Força Pública, (Santa Catarina. Decreto 1465A, 1921, p. 46) “[...]uma seção para serviços especiais de automóveis”, composta de "um 1. sargento, 4 segundos, 4 terceiros e 3 cabos [...]”.

Essa seção ocupava-se, especialmente, da manutenção dos veículos automotores que circulavam pelas ruas da capital catarinense, pois o artigo segundo desse decreto estabelece que (Santa Catarina. Decreto 1465A, 1921, p. 46) “Art. 2. ${ }^{\circ}$ - As praças para obterem a graduação de que trata o art. 1 ․ $^{\text {, }}$, serão submetidas a exame prático de mecânica, por uma comissão presidida pelo chefe das oficinas da Força Pública [...]”. Assim, percebemos, já no início da década de 1920, o estabelecimento de dispositivos legais de cunho estadual que se ocupavam, especialmente, do atendimento e da fiscalização à circulação operada pelos veículos motorizados.

Desse modo, a especialização de leis e dos serviços, destinados ao atendimento das necessidades e das exigências colocadas pela circulação automobilística, permite-nos considerar seu relativo grau de complexidade que, ao que parece, já assumia à época. Essas normas registram, por outro lado, o estabelecimento de dispositivos e órgãos de trânsito no Estado e na capital catarinense, recursos que objetivavam disciplinar e organizar o trânsito e a atividade de condutores de veículos. Para a cidade de Florianópolis, esses aspectos assumiram maior relevância, pois somente após a inauguração da ponte Hercílio Luz, em 1926, atestamos maior incremento à introdução de veículos motorizados e à organização e/ou adaptação de dispositivos regulamentares para disciplinar o trânsito da capital catarinense. Por outro lado, devemos lembrar, uma vez mais, que para os efeitos deste estudo, os órgãos e leis de trânsito implementados na cidade de Florianópolis sinalizam como um sintoma das necessidades e das exigências colocadas por novos elementos e personagens - automóveis e chauffeurs - no cenário urbano da Capital.

Neste ponto, é válido observarmos que, nos anos de 1914 e 1918, foram organizados e publicados os "regulamentos para as estradas estaduais" de Santa Catarina, que objetivaram organizar e/ou disciplinar, de maneira incipiente no Estado, o trânsito de veículos automotores ou operados a tração animal pelas ruas e estradas intermunicipais ${ }^{6}$. Nesses regulamentos, são registrados artigos referentes aos impostos cobrados (Santa Catarina. Decreto 846, 1914) “[...]

\footnotetext{
${ }^{6}$ Nesse ponto, é importante destacarmos o artigo segundo do Regulamento para as estradas estaduais, de 1918, que estipula que (Regulamento para as estradas estaduais a que se refere o Decreto 1116, 1918, p. 2) “Art. 2. ${ }^{\circ}$ - São estradas estaduais as que, pela sua extensão ou importância, devam ser submetidas à fiscalização imediata das autoridades estaduais”.
} 
em postos especiais, localizados nos pontos mais convenientes das estradas construídas pelo Estado, sendo o seu produto escriturado como renda especial [...] para ser exclusivamente aplicado na conservação e reconstrução das ditas estradas”.

Além dessas preocupações, os regulamentos supracitados estipulam, em seus capítulos e artigos, preocupações quanto: a) às obrigações dos proprietários marginais; b) ao trânsito de veículos operados a tração animal, como carros, carroças, tilburys, ou mecânicos: automóveis; c) às multas aplicadas às infrações cometidas contra os dispositivos existentes nos referidos regulamentos. Observamos, portanto, entre os anos de 1914 e 1918, a circulação simultânea, especialmente nas estradas de cunho intermunicipal, de automóveis e de veículos operados a tração animal. No regulamento datado do ano de 1914, o artigo 12, por exemplo, estipula, dentre outros dispositivos, que

Art. 12 - Os proprietários dos terrenos marginais das estradas são obrigados: \# $1 .^{\circ}$ - A limpar [...] as valas e as sarjetas laterais da estrada nos meses de junho a dezembro de cada ano, lançando os detritos a uma distância nunca menor de cinco metros para dentro de seus terrenos; si, porém, se der obstrução em outra qualquer época são obrigados a limpá-las em quinze dias; \# $2 .^{\circ}$ - A remover dentro de doze horas úteis, as árvores, pedras ou quaisquer outros objetos que, de seus terrenos desabem sobre o leito da estrada, valas e sarjetas; \# $3 .^{\circ}$ - A conservar perfeitamente desmatados e limpos 15 metros de seus terrenos, em cada lado da estrada; \# $4 .^{\circ}$ - A não plantar árvores de alto crescimento a menos de 15 metros de distância das valas e sarjetas (SANTA CATARINA. Decreto 846, 1914, p. 86).

Nas passagens destacadas, percebemos a nítida preocupação das autoridades estaduais em determinar a limpeza e a desobstrução dos terrenos marginais às estradas. Embora não esteja disposto textualmente, podemos concluir, com certa propriedade, que dentre os objetivos centrais das medidas aqui estipuladas, encontramos o de prover boas condições ao tráfego de veículos tracionados por força motriz animal, ou mesmo àqueles de natureza automotiva. Estabelecem, pois, normas que objetivam assegurar, para tanto, a desobstrução do "leito da estrada" e das "valas e sarjetas".

A circulação e a convivência simultânea dos automóveis e dos veículos tracionados por força motriz animal pelas estradas estaduais, verificadas já durante a década de 1910, podem ser melhor elucidadas ao observarmos as tabelas 01 e 02 , dispostas a seguir, pois elas registram, especialmente para os anos de 1914 e 1922, a expedição de cartas de habilitação para chauffeurs e boleeiros. A tabela 02, por exemplo, registra que, no ano de 1914, foram expedidas para as cidades de Florianópolis e Lages o total respectivo de quinze e uma carta 
para chauffeurs. No mesmo ano, a tabela correspondente aponta, para as cidades de Florianópolis e São José, a expedição de, respectivamente, duas e uma carta para boleeiros.

Neste ponto, vale observarmos que, no ano de 1922, todos os nove municípios, listados pela tabela 02, apresentavam registros crescentes do número de cartas extraídas para boleeiros, ao compararmos os dados correspondentes ao ano de 1914. Ao mesmo tempo, apenas cinco desses municípios apresentavam, no ano de 1922, registros crescentes do número de cartas extraídas para chauffeurs, ao compararmos com os dados dispostos para o mesmo ano precedente ${ }^{7}$. Esses aspectos reforçam a ideia de que os automóveis e os veículos acionados por força motriz animal circulavam, simultaneamente, pelas ruas de cunho estadual e, também, naquelas circunscritas ao perímetro urbano da capital catarinense. Apresentamos, a seguir, as tabelas 01 e 02 , referidas:

Tabela 01: Número de cartas expedidas no Estado de Santa Catarina (1911-1929)

\begin{tabular}{c|c|c|c}
\hline \multirow{2}{*}{ Anos } & Cartas para Chauffeurs & Cartas para Boleeiros / Cocheiros & Número Total de Cartas Expedidas \\
\hline $1911\left(^{*}\right)$ & ----- & 09 & 09 \\
1914 & 16 & 03 & 19 \\
1922 & 77 & $27(* *)$ & 188 \\
1929 & 87 & 150 & 332 \\
\hline
\end{tabular}

$(*)$ Os dados para este ano compreendem o total de cartas de boleeiros expedido entre os dias 12/04 e 15/05.

(**) Número correspondente ao total de cartas extraídas para carros, carroças e carretas no Estado de Santa Catarina, no ano de 1922.

Fontes: a) 1911: SANTA CATARINA. Relatório Apresentado ao Exmo. Sr. Coronel Vidal José de Oliveira Ramos, digníssimo Governador do Estado pelo Desembargador Sílvio de Sá Gonzaga, Chefe de Polícia, em 1. ${ }^{\circ}$ de junho de 1911. Florianópolis: Gab. Tip. d’ O Dia, 1911; b) 1914: SANTA CATARINA. Relatório Apresentado ao Exmo. Sr. Secretário Geral do Estado pelo Chefe de Polícia Ulysses Gerson Alves da Costa. Florianópolis, 14 maio de 1915; c) 1922: SANTA CATARINA. Relatório Apresentado ao Exmo. Sr. Dr. Joë Luiz M. Colaço, Secretário do Interior e Justiça pelo Desembargador Antero de Assis, Chefe de Polícia. Florianópolis, 1922.

Tabela 02: Número de cartas expedidas por município no Estado de Santa Catarina (19111922)

\begin{tabular}{|c|c|c|c|c|c|c|c|c|c|}
\hline \multirow{3}{*}{ Municípios } & \multicolumn{3}{|c|}{ Cartas para Chauffeurs } & \multicolumn{3}{|c|}{ Cartas para Boleeiros / Cocheiros $\left({ }^{*}\right)$} & \multicolumn{3}{|c|}{$\begin{array}{c}\text { Número Total de Cartas Expedidas por } \\
\text { Município }\end{array}$} \\
\hline & \multicolumn{3}{|c|}{ Anos } & \multicolumn{3}{|c|}{ Anos } & \multicolumn{3}{|c|}{ Anos } \\
\hline & 1911 & 1914 & 1922 & $1911(* *)$ & 1914 & 1922 & $1911\left(^{*}\right)$ & 1914 & 1922 \\
\hline Florianópolis & --- & 15 & 28 & 07 & 02 & 36 & 07 & 17 & 64 \\
\hline São José & --- & --- & --- & 02 & 01 & 05 & 02 & 01 & 04 \\
\hline Palhoça & --- & --- & --- & 01 & --- & 02 & 01 & --- & 02 \\
\hline Biguaçu & --- & --- & --- & --- & --- & 02 & --- & -- & 02 \\
\hline Santo Amaro & --- & --- & --- & --- & --- & 01 & --- & --- & 01 \\
\hline Lages & --- & 01 & 03 & --- & --- & 01 & --- & 01 & 04 \\
\hline Blumenau & --- & --- & 14 & --- & --- & 40 & --- & --- & 54 \\
\hline Itajaí & --- & --- & 07 & --- & --- & 05 & --- & --- & 12 \\
\hline Joinvile & --- & --- & 25 & --- & --- & 19 & --- & --- & 44 \\
\hline
\end{tabular}

\footnotetext{
${ }^{7}$ Ver, a respeito: a) 1914: SANTA CATARINA. Relatório Apresentado ao Exmo. Sr. Secretário Geral do Estado pelo Chefe de Polícia Ulysses Gerson Alves da Costa. Florianópolis, 14 maio de 1915; b) 1922: SANTA CATARINA. Relatório Apresentado ao Exmo. Sr. Dr. Joë Luiz M. Colaço, Secretário do Interior e Justiça pelo Desembargador Antero de Assis, Chefe de Polícia. Florianópolis, 1922.
} 


\begin{tabular}{l|c|c|c|c|c|c|c|c|c}
\hline $\begin{array}{l}\text { Total de Cartas } \\
\text { Expedidas }\end{array}$ & --- & 16 & 77 & 10 & 03 & 111 & 10 & 19 & 188 \\
\hline
\end{tabular}

(*) Número correspondente ao total de cartas extraídas para carros, carroças e carretas, respectivamente, para os anos de 1911, 1914 e 1922. (**) Os dados para este ano compreendem o total de cartas de boleeiros expedido entre os dias 12/04 e 15/05.

Fontes: a) 1911: SANTA CATARINA. Relatório Apresentado ao Exmo. Sr. Coronel Vidal José de Oliveira Ramos, digníssimo Governador do Estado pelo Desembargador Sílvio de Sá Gonzaga, Chefe de Polícia, em 1. o de junho de 1911. Florianópolis: Gab. Tip. d’ O Dia, 1911; b) 1914: SANTA CATARINA. Relatório Apresentado ao Exmo. Sr. Secretário Geral do Estado pelo Chefe de Polícia Ulysses Gerson Alves da Costa. Florianópolis, 14 maio de 1915; c) 1922: SANTA CATARINA. Relatório Apresentado ao Exmo. Sr. Dr. Joë Luiz M. Colaço, Secretário do Interior e Justiça pelo Desembargador Antero de Assis, Chefe de Polícia. Florianópolis, 1922.

Com base nos dados analisados, é possível inferirmos que a convivência simultânea de veículos automotores e daqueles tracionados por força motriz animal, especialmente pelas vias e estradas de cunho estadual, processou-se já em período anterior, pois é importante considerarmos que a organização de regulamentos para a fiscalização e a organização do tráfego de automóveis e de veículos não motorizados pelas estradas estaduais atesta, especialmente, a necessidade de oferecer respostas a problemas já postos, decorrentes, em parte, da crescente circulação desses veículos pelas estradas aqui referidas, conforme verificado anteriormente.

Além desses aspectos, fica evidente, já na década de 1910, a preferência concedida ao tráfego de veículos diversos: carros, carroças, tilburys, automóveis em detrimento à circulação dos transeuntes. Esse aspecto é registrado, de maneira especial, pelo Regulamento para as estradas estaduais, datado de 16 e 17 de abril de 1918, que estipula, dentre outros dispositivos, que dentre as "obrigações dos proprietários marginais”, destacamos:

Art. 30 - Todos os proprietários, inquilinos, arrendatários ou possuidores de terrenos marginais às estradas [são] obrigados a limpar e a conservar permanentemente, as valas e sarjetas laterais, lançando os restos de vegetação, a lama e os detritos, delas extraídas, a uma distância nunca inferior a cinco metros para dentro do terreno;

Art. 35 - Todas as árvores, pedras ou quaisquer objetos que dos terrenos caírem ou rolarem sobre o leito da estrada ou valas, serão por seus ocupantes removidos dentro de 12 horas;

Art. 36 - É igualmente vedado colocar, nos leitos ou valas, material de qualquer espécie, veículos, detritos ou quaisquer outros objetos, senão durante o tempo indispensável para que sejam transportados para o interior dos terrenos;

Art. 42 - Quando se houver de construir ou reconstruir cercas, muros, ou taipas laterais às estradas, proceder-se-á de modo a não as estreitar;

Art. 44 - As infrações de qualquer das disposições deste Capítulo serão punidas com a multa de $10 \$$ a 50\$000 (SANTA CATARINA. Regulamento para as estradas estaduais a que se refere o Decreto 1116, 1918, p. 2) ${ }^{8}$.

Além disso, assinalamos que, “para a boa conservação das estradas serão observadas”, dentre outros aspectos, que (Santa Catarina. Regulamento para as estradas estaduais a que se

\footnotetext{
${ }^{8}$ Esse regulamento foi baixado pelo Decreto 1116, de 10 de abril de 1918. Ver: SANTA CATARINA. Decreto 1116, de 10 de abril de 1918. Aprovando o regulamento para as estradas de rodagem estaduais. In: Colecção de Leis, Decretos e Resoluções de 1918. Florianópolis: Imprensa Oficial, 1919, p. 161.
} 
refere o Decreto 1116, 1918, p. 2) “Art. 15 - Todos os buracos ou depressões, que se formarem no leito da estrada, serão imediatamente aterrados [...]”.

Analisando esses artigos, ficam evidenciadas, em primeiro lugar, claras similitudes com os artigos e parágrafos destacados do regulamento datado do ano de 1914, anteriormente registrado. Assim, embora as disposições textuais de ambos os textos sejam ligeiramente diferentes, o que observamos são as proximidades de conteúdo e de mensagem nelas expressos. Desse modo, devemos observar a preocupação em se evitar a obstrução dos leitos das ruas e estradas estaduais, como o claro objetivo de permitir ou facilitar a livre circulação de veículos. Percebemos, portanto, a partir dos anos de 1914 e 1918, as preocupações das autoridades governamentais para beneficiar o trânsito de automóveis e de veículos operados a tração animal nas estradas estaduais. Além disso, devemos ponderar que a própria circulação dos veículos, sejam eles automotores, sejam tracionados por força motriz animal, condiciona as iniciativas tomadas pelos poderes públicos locais e estaduais para a elaboração de normas e dispositivos legais de trânsito; processo este que envolve, inegavelmente, conflitos e disputas políticas e ideológicas para a sua efetivação e resultados práticos.

É importante destacarmos o que estipula o artigo 28 do regulamento datado de 1918, pois nele se registra que (Santa Catarina. Regulamento para as estradas estaduais a que se refere o Decreto 1116, 1918, p. 2) “Art. 28 - Os serviços de conservação serão assiduamente fiscalizados pelos auxiliares técnicos da Diretoria de Obras Públicas, pelos Agentes de Terras e outros profissionais designados pelo Secretário Geral dos Negócios do Estado [...]”. Não nos cabe aqui, fazermos um estudo aprofundado sobre os serviços de fiscalização das estradas estaduais, durante o período compreendido entre os anos de 1914 e 1920. É importante, todavia, assinalarmos que, conforme observado anteriormente, foram estipuladas medidas práticas para a boa conservação das estradas estaduais. Além disso, existiam órgãos e agentes designados pelo Estado para os serviços de fiscalização das obras de melhoria e de conservação dessas estradas, ou seja, a esfera estadual, ao que parece, fazia-se presente para prover o bom gerenciamento das estradas e vias intermunicipais e essa presença era, senão, uma resposta às exigências colocadas pela circulação cotidiana de veículos pelas estradas catarinenses de cunho intermunicipal.

Durante a década de 1910, a circulação e a convivência simultâneas dos automóveis e veículos operados por força motriz animal pelas estradas estaduais tornaram-se evidentes, pois, ainda no ano de 1918, o artigo 48 do Regulamento para as estradas estaduais a que se refere o Decreto 1116, de 10 de abril, estipula que (Santa Catarina. Regulamento para as estradas estaduais a que se refere o Decreto 1116, 1918, p. 2) “Art. 48 - Ninguém poderá 
conduzir veículos pelas estradas sem estar devidamente habilitado com a carta de boleeiro ou motorista [...]”. Além disso, a habilitação era vedada aos menores de 18 anos, pois o indivíduo deveria (Santa Catarina. Regulamento para as estradas estaduais a que se refere o Decreto 1116, 1918, p. 2) “Art. 51 - Juntar provas de que é maior de dezoito anos, de bom comportamento [...]”. Percebemos, por outro lado, que a categoria “veículos” envolvia aqueles tracionados por força motriz animal e, também, os de natureza automotiva.

Em vista disso, podemos considerar que esse elemento sinaliza para o fato de que, ao final da década de 1910, não tínhamos - pelo menos em âmbito legislativo - exata clareza sobre a denominação que se deveria empregar para referir-se, de modo especial, aos veículos automotores; aspecto este que será, gradualmente, equacionado por ocasião da elaboração do Regulamento para o serviço policial do Estado (1920) e das Instruções Regulamentares para o serviço de trânsito público (1928).

As determinações estipuladas no artigo 48, supracitado, envolviam, ao que parece, todos os condutores que circulavam pelas vias e estradas estaduais, pois conforme o artigo 50, deste regulamento (Santa Catarina. Regulamento para as estradas estaduais a que se refere o Decreto 1116, 1918, p. 2), “Art. 50 - Nos municípios, onde não houver serviço organizado de exames de boleeiros ou motoristas, os candidatos poderão habilitar-se perante os delegados de polícia [...]”. A habilitação era, entretanto, como visto, vedada aos menores de dezoito anos. O que percebemos é que os condutores de veículos automotores ou tracionados por força motriz animal deveriam estar legalmente habilitados para terem o direito de guiar os seus veículos. Além disso, a habilitação para dirigir parece ter alcançado um significativo grau de importância; pois, mesmo nos municípios em que não havia serviços específicos destinados à sua obtenção, ela era intermediada pelas autoridades policiais locais. Assim, os elementos registrados pelos artigos 48 e 51, anteriormente referidos, foram ratificados, de modo especial, pelo Regulamento para o serviço policial do Estado, de 1920.

A partir dos anos de 1920 e 1921 a obrigatoriedade para a obtenção da carta foi, todavia, exigida apenas daqueles indivíduos que conduziam veículos automotores, conforme estipula, como visto, a Lei Estadual 1325, de 18 de agosto de 1920. O que observamos, entre os anos de 1918 e 1920, são mudanças referentes às normas de trânsito, notadamente quanto ao direito de conduzir automóveis; pois, a partir do início da década de 1920, apenas aqueles que conduziam veículos automotivos eram obrigados a serem legalmente habilitados para tal 
prática. Esse aspecto vigorou, pelo menos, até o ano de 1928, por ocasião da publicação das Instruções Regulamentares para o serviço de trânsito público ${ }^{9}$.

Neste artigo, objetivamos tecer uma investigação circunscrita ao âmbito da capital catarinense - observando, naturalmente, as correlações com outros centros urbanos nacionais e da Europa Ocidental -, e não propriamente relacionada ao Estado de Santa Catarina. É válido, entretanto, mencionarmos novamente o registro já referenciado, que atesta, em período um pouco anterior à década de 1920, o estabelecimento de regulamentos específicos que apresentavam, textualmente, como principal objetivo, o ato de organizar e disciplinar o tráfego de veículos pelas estradas estaduais de Santa Catarina. Ressaltamos, todavia, que para os efeitos deste estudo, apenas no início da década de 1920 atestamos, especialmente em Florianópolis, a nítida implantação de disposições e de órgãos regulamentares de trânsito que se ocuparam não apenas dos veículos operados a tração animal, mas, principalmente, dos novos elementos componentes da cena urbana: os automóveis.

\section{Legislação e Municipalidade}

Nesta parte objetivamos discutir, até que ponto as regras e as normas de trânsito implementadas na cidade de Florianópolis, especialmente a partir das décadas de 1910 e 1920, apresentaram alterações e/ou adaptações em relação às legislações que norteavam, pelo menos desde o final do século XIX, a circulação dos carros e carroças operados por força motriz animal, para, dentre outros objetivos, atender à circulação dos automóveis? Nesse sentido, procedemos a uma análise dos textos dos códigos de posturas municipais datados dos anos de 1889 e 1896. Esses textos serviram para tecermos uma análise paralela sobre os aspectos técnico e moral envolvidos na adoção de normas legais relativas à adequação de ruas e edificações para, dentre outros aspectos, prover melhores condições ao tráfego e deslocamento de veículos.

De outro modo, analisamos, também, as percepções expressas pelos órgãos governamentais locais a respeito das tentativas colocadas em prática para prover o saneamento e a higienização do perímetro urbano da capital catarinense; situação esta que será relacionada aos contextos dos principais centros urbanos do País, no período. Essas tentativas disciplinadoras dos ambientes urbanos em questão objetivaram, em síntese, adequá-

\footnotetext{
${ }^{9} \mathrm{O}$ artigo primeiro desse texto aponta que (Santa Catarina. Instruções Regulamentares para o serviço de trânsito público, 1928, p. 6) "Art. $1^{\circ}$ - Os condutores de veículos de qualquer natureza deverão estar munidos, quando em serviço, da respectiva caderneta de habilitação [...]”.
} 
los às posturas civilizatórias propagadas pelas elites locais, posturas essas observadas, especialmente, naquelas facções ligadas ao viés republicano, uma vez que almejavam - ao menos em teoria - o progresso material e moral da sociedade brasileira da época, vedado aos seus estratos sociais inferiores.

Neste ponto, registramos que em pesquisa realizada na Biblioteca Pública do Estado, encontramos os códigos de posturas municipais de Florianópolis relativos aos anos de 1889 e 1896. À primeira vista, salta-nos aos olhos a similitude dos conteúdos registrados nessas publicações. Eles abordam temáticas diversas: a) alinhamento e nivelamento de ruas; b) conservação de estradas e caminhos; c) higiene e saúde pública; d) condutores e trânsito de carros, carroças e animais; e) disposições sobre o serviço de bondes etc. Em todas as três publicações, observamos a clara similaridade existente nos conteúdos dispostos pelos vários títulos e capítulos por elas apresentados. Estes, salvo pequenas alterações, são similares e tratam de temas correlatos. É importante percebermos que, em nenhum dos artigos das publicações supracitadas, há menção aos termos automóvel ou chauffeur, ou seja, essas publicações tratam, nos capítulos correspondentes, apenas do trânsito de veículos operados por força motriz animal.

Assim, por exemplo, o capítulo correspondente ao "trânsito de carros, carroças e animais”, disposto no código de posturas do ano de 1889, trata, especialmente, da obrigatoriedade de (Desterro, Código de Posturas, 1889, p. 28) “[...] todos os carros, carroças e qualquer veículo particular ou de aluguel, empregados em serviços da cidade [...]”, serem matriculados anualmente - ver, especialmente, dessa publicação, o artigo 141. Esse mesmo código também registra, no artigo 147, que (Desterro, Código de Posturas, 1889, p. 29) “Art. 147 - [...] em nenhum caso, serão admitidos a matrícula aos menores de dezoito anos [...]”.

Vale registrarmos que, já na última década dos oitocentos, havia a obrigatoriedade para que todos os condutores de "carros, carroças, ou outros quaisquer veículos de boleia” estivessem regularmente matriculados na "secretaria de polícia”, conforme estipula o artigo 145 do código de posturas aqui já referido ${ }^{10}$. Assim, o que percebemos é que, já no final do século XIX, havia determinações legais que estipulavam a obrigatoriedade para que todos os condutores, maiores de dezoito anos, estivessem regulamente matriculados; condições exigidas para conceder-se o direito à condução dos veículos. Esses elementos continuaram a

\footnotetext{
${ }^{10}$ DESTERRO. Câmara Municipal da Cidade do Desterro. Código de Posturas. Lei 1238, de 22 de outubro de 1888. Desterro: Tipografia da Regeneração, 1889.
} 
ser exigidos no século seguinte, conforme vimos na seção anterior, por ocasião das análises efetuadas nos artigos e conteúdos apresentados pelos regulamentos estaduais de 1914 e 1918.

Outro elemento que julgamos importante é o fato de que muitos dos artigos dispostos nos códigos de posturas dos anos de 1889 e 1896 são similares àqueles registrados pelo Regulamento para o serviço policial do Estado (1920), notadamente quanto às exigências e à obrigatoriedade para que os condutores de veículos estivessem regularmente habilitados; e quanto às "obrigações comuns a todos os cocheiros, carroceiros e motoristas”, que deveriam, dentre outros elementos,

[...] apresentar-se vestido com asseio e decência; [...] tratar com polidez e atenciosa deferência o passageiro, evitando toda e qualquer alteração com o mesmo; [...] guiar com prudência os animais, carros, bondes, automóveis, para evitar prejuízos aos transeuntes e passageiros [...] (SANTA CATARINA. Regulamento para o serviço policial do Estado, 1920) ${ }^{11}$.

Neste ponto, é possível percebermos que os "transeuntes" e os "passageiros" determinavam, também, o ritmo de deslocamento dos veículos e que não devemos, portanto, adotar posturas unilaterais, nas quais apenas os chauffeurs e boleeiros, ao guiarem automóveis e carros, tinham o pleno direito ao uso e deslocamento pelas ruas do perímetro urbano da cidade de Florianópolis. Devemos atentar para o fato de que, nessas passagens, observamos, os termos “motoristas” e “automóveis”. Notamos, portanto, que o Regulamento para o serviço policial do Estado tem por objetivo atender, também, ao trânsito de veículos motorizados ${ }^{12}$. É este, precisamente, o principal avanço dessa publicação em relação ao conteúdo apresentado pelos códigos de posturas municipais de Florianópolis, anteriormente referenciados. Podemos, igualmente, constatar esse avanço ao observarmos os conteúdos dos "regulamentos das estradas estaduais”, datados dos anos de 1914 e 1918, referenciados na seção anterior.

Em outras palavras, podemos afirmar, com certa propriedade, que entre o final do século XIX e as primeiras décadas do século seguinte houve, ao que parece, uma apropriação

\footnotetext{
${ }^{11}$ Para não nos alongarmos em demasia sobre esses aspectos, é suficiente ver os artigos 113, 115, 120 e 121 - e parágrafos correspondentes - do Regulamento para o serviço policial do Estado, de 1920. (SANTA CATARINA. Regulamento para o serviço policial do Estado. Florianópolis: Tipografia da Livraria Central, 1920). Conteúdos similares são encontrados junto aos artigos 145, 146, 147, 149 e 150 do código de posturas de 1889 e aos artigos 152, 153, 154, 156 e 157, do código de posturas de 1896. Ver, a respeito: a) DESTERRO. Câmara Municipal da Cidade do Desterro. Código de Posturas. Lei 1238, de 22 de outubro de 1888. Desterro: Tipografia da Regeneração, 1889; e b) FLORIANÓPOLIS. Código de Posturas Municipais de Florianópolis. Florianópolis: Tipografia da República, 1896.

${ }^{12}$ O Regulamento para o serviço policial do Estado abrange também o trânsito em âmbito municipal, diferente, por exemplo, do Regulamento das estradas estaduais e respectivo imposto de trânsito a que se refere o Decreto 846, de 29 de dezembro de 1914, que trata do trânsito nas estradas de cunho estadual. Daí porque o nosso objetivo em chocar as informações registradas no regulamento policial de 1920 com aquelas referenciadas nos códigos de posturas municipais aqui discutidos.
} 
dos elementos dispostos nos capítulos e artigos dos códigos de posturas municipais supracitados para a elaboração dos “regulamentos das estradas estaduais" dos anos de 1914 e 1918; e, especialmente, do Regulamento para o serviço policial do Estado, de 1920, com o objetivo de regularizar, dentre outros aspectos, a circulação do automóvel, que se coloca, portanto, como novo elemento presente nas vias intermunicipais e nas ruas do perímetro urbano da capital catarinense, a partir daquele período.

Dentre as preocupações assinaladas pela administração municipal para disciplinar o espaço público da cidade de Florianópolis, a fim de melhor organizar o tráfego de veículos e pedestres, encontramos o que determina os artigos 162 e 165 do Código de Posturas de 1889. Assim, destacamos que (Desterro, Código de Posturas, 1889, pp. 32-33) “Art. 162 - Aos carroceiros ou condutores de carroças, carrinhos de mão e outros veículos empregados no trânsito de carga, materiais etc. no perímetro da cidade [...]”, fica designada “Art. 165 - A parte da rua do Príncipe [atual rua Conselheiro Mafra], entre a Alfândega e a continuação da rua Trajano, para ponto de estação de tais veículos, que deverão se conservar sempre alinhados [...]”. Observamos, portanto, desde o final do século XIX, a adoção de medidas específicas destinadas a prover melhor organização e acondicionamento à circulação de veículos, animais e transeuntes pelas ruas e logradouros do perímetro urbano da cidade de Florianópolis.

Neste ponto, devemos fazer uma importante observação, pois, para os efeitos deste estudo, os códigos e normas de trânsito teorizados para a capital catarinense envolviam ou procuravam amalgamar interesses diversos: daqueles responsáveis por sua elaboração teórica e aplicação prática - legisladores, políticos, engenheiros -, bem como das próprias atitudes e usos expressos pelo homem comum no cotidiano da cidade. Assim, as práticas e os costumes cotidianos exercidos pelos florianopolitanos nas ruas, logradouros e locais públicos da capital catarinense foram elementos que, de uma ou outra forma, influenciaram, direta ou indiretamente, na elaboração e na aplicação de leis e códigos de trânsito, instituídos pelos poderes públicos municipal e estadual para o âmbito da cidade de Florianópolis. Nesse sentido, o artigo 161 do código de posturas de 1889, descrito anteriormente, pode ser interpretado como uma tentativa de se disciplinarem antigas práticas exercidas pelos habitantes da capital catarinense, uma vez que proíbe, por exemplo, em seus parágrafos segundo e sétimo (Desterro, Código de Posturas, 1889, pp. 31-32), “Art. 161 - \# 2. ${ }^{\circ}$ - O trânsito de qualquer veículo ou animal junto dos passeios ou sobre eles [...]”, e “\# 7. - O trânsito de carros de eixo rangendo pela cidade [...]”. Além disso, essas passagens permitem- 
nos vislumbrar que tais práticas eram, mesmo, exercidas durante muito tempo pelos habitantes da cidade, e que frente ao novo regime político em voga - o código de posturas referido foi publicado no ano de 1889 - precisaram, ao menos em caráter teórico, ser disciplinadas por meio de regras e dispositivos regulamentares de trânsito, dispostos e organizados no referido código de posturas.

Desse modo, as preocupações quanto à disciplinarização do tráfego de veículos e pedestres, assim como quanto aos demais capítulos e artigos dessa publicação, envolvem, ao que parece, claros interesses políticos atinentes à "necessidade” de oferecer-se à capital do Estado um conjunto de leis e regulamentações urbanas que assinalassem a passagem para o novo regime político ${ }^{13}$. Nesse sentido, podemos considerar que as autoridades municipais almejaram elaborar uma legislação para a cidade do Desterro - ao menos em seu caráter retórico - com o objetivo de tentar “apagar” os elementos e características do que entendiam ser o passado “imperial” e "atrasado" da cidade.

Além disso, vimos que a circulação dos automóveis era incipiente no Estado durante o início da década de 1920, e que só seria regulamentada, com maior propriedade, por ocasião da elaboração do Regulamento para o serviço policial do Estado (1920); tráfego este que apresentava gradual crescimento e que necessitava de reaparelhamento normativo ou preparação das vias trafegáveis para melhor acondicioná-lo.

O texto referente ao Código de Posturas municipais de 1889 nos permite tecer algumas reflexões sobre as determinações do poder público municipal quanto ao saneamento e à higienização do espaço central da capital catarinense. Assim, destacamos que

Art. 53 - É absolutamente proibido: \# 1. $^{\circ}$ - Lançar cisco, palhas, vidros, imundices, materiais fecais, animais mortos, lixo, entulhos, nos quintais, praças, ruas, Cais, praias ou nos terrenos compreendidos no perímetro da cidade e povoações [ou naqueles locais] designados pela Câmara para edificações, [assim como] conservar lamaçais ou águas estagnadas, cloacas abertas, urinar ou fazer dejeções nos mesmos lugares [...] (DESTERRO, Código de Posturas, 1889, p. 14).

Os parágrafos segundo e quinto desse artigo especificam que não eram permitidas a criação de (Desterro, Código de Posturas, 1889, p. 14) “\# 2. - Porcos dentro da cidade e seus

\footnotetext{
${ }^{13}$ Observemos que a aprovação do Código de Posturas da cidade de Florianópolis, datado de 1896, cujos artigos e parágrafos são, em grande parte, similares ao texto de 1889, envolveu interesses políticos, notadamente para registrar, sob o ponto de vista da administração pública municipal, um novo momento para a capital catarinense, que, a partir do ano de 1894, passou a ser denominada Florianópolis. Esse ato coroou, simbolicamente, a vitória das elites republicanas no Estado. Ver, a respeito, SANTA CATARINA. Lei 111 , de $1 .^{\circ}$ de outubro de 1894 . Altera o nome da cidade do Desterro para Florianópolis. Florianópolis, 1894.
} 
arrabaldes ou trazê-los a solta nas outras povoações [...]”; além das práticas de se “\# $5 .^{\circ}$ Estender ou conservar nas praças e ruas quaisquer materiais de cheiro infecto ou objetos que embaracem o trânsito público [...]”. Além disso, outra determinação estipula que (Desterro, Código de Posturas, 1889) “Art. 54 - A limpeza das águas servidas e materiais fecais só será feita das dez horas da noite às cinco da manhã, lançando-se-as ao mar [...]”. Corroborando com esses elementos, o Código de Posturas de 1889 destaca que

Art. 130 - É proibido: \# $1 .^{\circ}$ - Fazer bulhas ou vozeiras, dar altos gritos sem necessidade reconhecida [...]; \# $2^{\circ}{ }^{\circ}$ - Fazer sambas ou batuques, quaisquer que sejam as denominações, dentro das ruas da cidade ou das povoações [...] (DESTERRO, Código de Posturas, 1889, p. 25).

O mesmo código determina, nos parágrafos quinto e nono, que é proibido:

\# 5. ${ }^{\circ}$ - Proferir palavras obscenas ou licenciosas que ofendam o pudor das famílias ou a moralidade pública "e” \# 9. - Andar pelas ruas indecentemente vestido, com roupas dilaceradas, ou sem que traje, pelo menos, calça e camisa, sendo esta por dentro daquela [...] (DESTERRO, Código de Posturas, 1889, p. 25).

Assim, os artigos e respectivos parágrafos assinalados anteriormente permitem-nos tecer considerações importantes. Em primeiro lugar, observamos que o poder público municipal determinava, com maior clareza a partir daquele período, proibições quanto às ações de despejo de materiais e elementos que provocariam odores ou depreciações à plástica urbana; devia-se, portanto, conservar limpos, dentre outros locais, os “[...] quintais, praças, ruas e os terrenos compreendidos no perímetro da cidade e povoações”. De outro modo, conferiu-se especial atenção à livre fluência do trânsito público. Outro aspecto que consideramos importante diz respeito às costas litorâneas e às praias que configuravam, à época, espaços em que se permitiam, legalmente, o despejo de materiais não condizentes às tentativas de higienização do perímetro urbano da capital catarinense.

Nos textos registrados anteriormente, é possível percebermos que o conjunto de determinações municipais pretendeu penetrar nas sociabilidades e valores do povo. Assim, foram estipuladas proibições aos hábitos e costumes populares; pois, dentre outros aspectos, "os sambas e batuques" foram impedidos de serem praticados "nas ruas e povoações da cidade”. Além disso, foram rechaçadas práticas relativas à pronúncia de palavras ou expressões consideradas chulas e à circulação de pessoas maltrapilhas ou vestidas de maneira 
vista como inadequada. Desse modo, o que percebemos, já naquela época, é que havia preocupações, por parte do poder público da Capital, em conferir à cidade um aspecto higienizado e aprazível.

Não devemos esquecer que o ano de 1889 marca o início de um novo regime político para o País. A par da consideração de que a proclamação de 1889 apenas assinalou o findar de um regime político que, desde pelo menos a década de 70 do século XIX, já mostrava claros sinais de saturação e esgotamento, podemos assinalar que a organização e a publicação do código de posturas municipal da cidade de Florianópolis (Desterro), datado daquele ano, envolveram, dentre outros elementos, a preocupação em elaborar ou, ao menos, reordenar artigos e dispositivos legais relativos aos principais procedimentos quanto à disciplinarização do espaço urbano e das práticas e vivências populares.

As medidas relativas à higienização do espaço urbano da capital catarinense e à proibição de costumes praticados pela população florianopolitana que, no entendimento das elites locais, não eram condizentes com o asseio e a civilidade, tornaram-se mais incisivas durante as primeiras décadas do século $\mathrm{XX}$ e foram propaladas, especialmente, pelos periódicos e órgãos governamentais locais. Nesses instrumentos, percebemos uma profícua discussão sobre as medidas para o equacionamento de doenças infectocontagiosas e sobre a salubridade dos espaços públicos da cidade de Florianópolis.

Discutir a questão sanitária na Capital nesse período, como, por exemplo, as doenças, a implementação de serviços de saneamento básico, é fundamental para compreendermos os objetivos da ação governamental nas modificações, higienização e embelezamento da parte central da cidade, pois o governador Hercílio Luz, por exemplo, ao iniciar seu segundo mandato (1918-1922) ${ }^{14}$, declarou que o saneamento, especialmente na região do litoral, era (Mensagem, 1919, p. 18) “[...] o problema, sobre todos, capital, sem cuja solução teremos de assistir impotentes à derrocada de nossos esforços em prol da prosperidade do Estado [...]”.

O governo de Hercílio Luz representou, para a política local, a consolidação dos ideais republicanos e federativos, simpáticos às iniciativas progressistas e à noção de modernidade; valores estes que se refletiram em mudanças quanto aos enfoques conferidos, por exemplo, à educação. Essa foi pautada pela formação técnica, que era destinada à preparação de profissionais para atuarem, majoritariamente, de maneira prática e direta, nos campos da

\footnotetext{
${ }^{14}$ Hercílio Luz governou o Estado em três oportunidades: a) 1894-1898; b) 1918-1922 (Vice-governador eleito com Lauro Muller; exerceu o cargo durante o quatriênio face ao pedido de licença do titular); e c) 1922-1924. Ver, a respeito, MEIRINHO, Jali. República e Oligarquias: subsídios para a história catarinense - 1889-1930. Florianópolis: Insular, 1997, p. 127.
} 
engenharia e medicina - O Instituto Politécnico de Florianópolis, por exemplo, foi fundado e organizado entre os anos de 1921 e 1923; deu-se, pois, durante o governo de Hercílio Luz ${ }^{15}$.

A educação objetivava, no período, formar técnicos cujas capacidades profissionais fossem direcionadas para equacionar os problemas de saneamento e de higienização do espaço público da Capital. Essas políticas estiveram presentes - e com maior envergadura na esfera federal, sobretudo nos grandes centros urbanos: Rio de Janeiro, São Paulo, Recife; cujas administrações locais coordenaram esforços direcionados para a efetuação de ações, muitas vezes pontuais, voltadas para o equacionamento dos seus principais problemas sanitários e paisagísticos.

No âmbito da capital catarinense, a Mensagem apresentada pelo superintendente Antônio Pereira da Silva e Oliveira ao Conselho Municipal da cidade de Florianópolis, em 1905, expressa a preocupação com a salubridade do espaço central da cidade; pois, sem a (Mensagem, 1905, p. 2) “[...] adoção de medidas que tornem obrigatório o serviço de remoção de matérias fecais e do lixo, proibindo em absoluto o despejo em quintais (principalmente no centro da cidade) [...]”, ou em “[...] qualquer parte dentro do perímetro urbano será impossível, ou pelo menos muito difícil, tornar em realidade o saneamento da nossa capital [...]”. Assim, o Superintendente municipal em questão assinala que (Mensagem, 1905, p. 2) “Parece-me ser este o único meio para de uma vez para sempre, extinguirmos os depósitos de lixo e os poços de materiais fecais que ainda hoje infelizmente existem em acanhados quintais no centro da cidade [...]”. Além disso, referencia que a (Mensagem, 1905, p. 2) “[...] desagradável impressão que causam as velhas e feias casas da rua Arcipreste Paiva com fundos para a rua Padre Miguelinho, que se tornaram [...] focos de infecção, impõem a necessidade urgente de sua desapropriação, não só para embelezamento, como medida de higiene da cidade [...]”. Quinze anos depois, o artigo do jornal República, de $10^{\circ}$ de fevereiro de 1920, salienta a mesma preocupação ao observar que

Florianópolis, a mais formosa Ilha do Atlântico, está, atualmente, sofrendo a influência benéfica da administração progressista, modelar do eminente catarinense sr. Dr. Hercílio Luz, que vai executando no seu governo um vasto programa de melhoramentos indispensáveis. Mister se tornava saneála, embelezá-la de acordo com o adiantamento moral, material, intelectual de Santa Catarina, cujo grau de prosperidade era constantemente assinalado e conhecido, através das manifestações da imprensa de todo o País. Com uma feição rotineira, colonial, com suas ruas estreitas, com inúmeros casebres a enfear-lhe a estética, Florianópolis impressionava mal ao forasteiro. O beco Irmão Joaquim, com os seus cortiços margeando o canal da Fonte da Bulha

\footnotetext{
${ }^{15}$ VEIGA, Eliane Veras da. Florianópolis: memória urbana. Florianópolis: UFSC/Fundação Franklin Cascaes, 1993, pp. 261-
} 263. 
até a pedreira, era um verdadeiro foco de miasmas e um conhecido antro de vadiagem. Os casebres não tinham instalações de esgotos. As dejeções eram feitas no canal. Quilômetros acima, rumando o leito da Fonte da Bulha, a mesma prática das moradias pobres, sem noção [...] dos bons ensinamentos da higiene. A situação exigia uma vontade disciplinada que executasse um grandioso plano de melhoramento da cidade, extinguindo males inveterados (Remodelação de Florianópolis. República, 1920, p. 1).

A par do caráter ufanista e simpatizante às ações do governo estadual expresso pelo artigo do jornal em destaque - o periódico era dirigido por integrantes ou simpatizantes do Partido Republicano local -, as ideias referidas salientam, durante aproximadamente quinze anos, as preocupações quanto ao embelezamento e à higienização do espaço público relativo ao perímetro urbano da cidade de Florianópolis. Neste ponto, é importante destacarmos que os problemas referentes ao abastecimento de água potável na cidade ou, mesmo, ao equacionamento dos problemas ligados à salubridade da região central da urbe por meio, dentre outras medidas, das discussões para a remoção do antigo outeiro da cidade, estiveram presentes durante os séculos XVIII e XIX ${ }^{16}$. Entretanto, podemos considerar que, a partir do final do século XIX, até, pelo menos, a década de 1920, as preocupações quanto à salubridade e à higienização do perímetro urbano da cidade de Florianópolis assumiram, junto aos periódicos e órgãos governamentais locais, um teor mais enfático e evidente.

Desse modo, na Capital, durante as primeiras décadas do século XX, médicos, autoridades e políticos descreviam, de maneira dramática, os problemas de saneamento e propunham várias medidas, desde a distribuição gratuita de remédios até o controle dos movimentos populacionais no espaço urbano. Um tom de urgência impregnou, portanto, as manifestações sobre a saúde pública em Santa Catarina, especialmente em Florianópolis, como se os surtos de doenças fossem inusitados para a sociedade daquela época ${ }^{17}$.

As doenças mencionadas não eram novas na região e elas se manifestavam em Nossa Senhora do Desterro desde o século XVIII, conforme relatam antigos cronistas e viajantes ${ }^{18}$. O que teria acontecido para que, nas vésperas dos anos 1920, elas passassem a ser vistas como um problema sanitário de proporções inéditas? Uma aguda deterioração das condições gerais

\footnotetext{
${ }^{16}$ Sobre tais discussões ver, por exemplo, a) SANTA CATARINA. RIBEIRO, João Alberto Miranda. Ofícios recebidos pela Câmara do Governador João Alberto Miranda Ribeiro. Desterro, 26 jun. 1794; b) SANTA CATARINA. COUTINHO, João José. Relatório apresentado à Assembleia Provincial de Santa Catarina. Desterro, 19 abr. 1854; e c) SANTA CATARINA. ROCHA, Francisco José da. Relatório apresentado à Assembleia Legislativa Provincial de Santa Catarina. Rio de Janeiro, 1888.

17 ARAÚJO, Hermetes Reis de. Fronteiras Internas: Urbanização e Saúde Pública em Florianópolis nos anos 20. In: BRANCHER, Ana (Org.). História de Santa Catarina: estudos contemporâneos. Florianópolis: Letras Contemporâneas, 1999, p. 103.

${ }^{18}$ ARAÚJO, Hermetes Reis de. Fronteiras Internas: Urbanização e Saúde Pública em Florianópolis nos anos 20... op. cit., p. 103. Uma discussão mais aprofundada sobre os enquadramentos sociais que se objetivavam traçar à população florianopolitana como forma de disseminar valores considerados morais e civilizatórios é encontrada no texto: ARAÚJO, Hermetes Reis de. A invenção do litoral: Reformas urbanas e reajustamento social em Florianópolis na Primeira República. Dissertação (Mestrado em História). São Paulo: PUC, 1989.
} 
de saúde? Nem tanto, pois a saúde pública, no início do século $\mathrm{XX}$, não estaria sendo comprometida por males muito mais graves do que aqueles que ocorriam nas décadas passadas. Assim, as causas para o surgimento de um problema sanitário ameaçador não se encontram num agravamento das doenças ou numa sensível diminuição dos cuidados com a saúde pública, que não haviam mudado de maneira significativa no início do século passado.

A resposta mais imediata indicaria o fato de que surgiu uma nova percepção daquelas doenças em Santa Catarina. Elas teriam adquirido um novo significado em termos de ameaça à saúde e passaram, consequentemente, a demandar formas de prevenção mais eficazes. $\mathrm{O}$ aparecimento dessa nova modalidade de enquadramento e combate às epidemias não se deve, contudo, somente à utilização da ciência para resolução dos problemas de saúde pública. Outros fatores também foram decisivos na mudança de relação com a doença; entre eles, dois se destacam. O primeiro foi uma crescente intervenção do Estado na sociedade, por meio de campanhas de profilaxia, inspeções sanitárias e implantação de reformas urbanas. O segundo corresponde a uma crescente diferenciação social, que identificou uma insuficiência de civilização nos costumes locais e reclassificou os espaços e os indivíduos passíveis de abrigar aquelas doenças como um novo tipo de ameaça para a cidade e seus habitantes ${ }^{19}$.

A importância conferida à saúde pública a partir do final do século XIX, no Brasil, é explicada, em grande parte, pelas transformações socioeconômicas ocorridas no país. Neste quadro, os recursos gerados pela economia agroexportadora, especialmente o café, atraíam investimentos estrangeiros aplicados em bancos, ferrovias e obras de infraestrutura. Em vista disso, a atividade comercial foi incrementada, assim como a oferta e a disponibilidade de serviços urbanos.

Destacamos, também, o crescimento demográfico experimentado no período especialmente aplicado às cidades do Rio de Janeiro e São Paulo - que se chocou com uma infraestrutura urbana incapaz de acolher tal aumento de contingentes; e, desse modo, essas cidades apresentaram um processo gradual de inchamento populacional, em função do seu crescimento desordenado ${ }^{20}$. Outrossim, verificamos, de maneira paralela, o agravamento das condições sanitárias, despontando várias áreas insalubres e focos endêmicos de doenças infectocontagiosas: cólera, varíola, tuberculose, febre amarela.

\footnotetext{
${ }^{19}$ ARAÚJO, Hermetes Reis de. Fronteiras Internas: Urbanização e Saúde Pública em Florianópolis nos anos 20... op. cit., p. 104.

${ }^{20}$ As populações das cidades do Rio de Janeiro e de São Paulo cresceram rapidamente com a chegada contínua de imigrantes estrangeiros. Entre 1900 e 1920, a população de São Paulo saltou de 240.000 para 579.000 habitantes e a do Rio de 800.000 para 1.150.000. Como não havia uma infraestrutura urbana capaz de acolher tal aumento demográfico, essas cidades começaram a apresentar um processo de inchamento, em função do seu crescimento desordenado. Sobre os dados demográficos aqui apresentados para as cidades de São Paulo e Rio de Janeiro, ver: IBGE. Anuário Estatístico do Brasil, Rio de Janeiro, 1999, v. 59.
} 
A partir desse momento, notamos que se configura uma crise sanitária nos principais centros urbanos. Ela expôs, abertamente, as precárias condições de saneamento no Brasil e ensejou a mobilização de recursos para a formação de uma estrutura de saúde pública mais eficiente. No Rio de Janeiro, a solução para os problemas sanitários foi estreitamente associada a um amplo programa de reformas urbanas. Foi a época "do bota abaixo”, quando foram demolidos vários quarteirões populares no centro da cidade e, consequentemente, seus moradores foram expulsos para ceder lugar a praças e avenidas, como a Avenida Central, inaugurada em 1904 e entregue ao tráfego em 1905, que logo se tornou o símbolo máximo de uma nova concepção urbanística no país ${ }^{21}$.

Devemos observar que a construção dessa avenida - assim como das principais obras de infraestrutura efetuadas no espaço central da capital carioca no período - obedeceu aos princípios de circulação e de salubridade urbanos, almejados por muitos setores que compunham a elite carioca. Por outro lado, entre as iniciativas tributárias desse modelo nas capitais brasileiras da época, destacamos a construção e a inauguração das seguintes avenidas: a) Sete de Setembro em Salvador (1912-1916); b) Rio Branco e Marquês de Olinda no Recife (década de 1910); e c) Avenida Borges de Medeiros em Porto Alegre (projetada em 1914 e concluída em 1920) ${ }^{22}$. Essas iniciativas também estavam presentes na maioria das propostas para os melhoramentos urbanos da cidade de São Paulo ${ }^{23}$. Desse modo, a capital paulista também sofreu, nessa época, alterações significativas em seu espaço urbano, sobretudo no governo municipal de Antônio Prado. Personagem emblemático das primeiras etapas do processo de intensa urbanização da capital paulista, Antônio Prado era vinculado à atividade cafeeira, mas simpatizava com a crescente diversificação de atividades verificadas na cidade de São Paulo.

É válido observarmos que Antônio Prado dedicou seus doze anos de mandato - de 1899 a 1910 - à remodelação física dos espaços e equipamentos urbanos da capital paulista. Neste ponto, podemos relacionar esse processo com aquele sofrido pela cidade do Rio de Janeiro; pois, no mesmo período, grande parte dos investimentos federais aplicados na infraestrutura urbana estava voltada para as obras realizadas na capital fluminense, empreendidas pelo

\footnotetext{
${ }^{21}$ ARAÚJO, Hermetes Reis de. Fronteiras Internas: Urbanização e Saúde Pública em Florianópolis nos anos 20... op. cit., p. 105.

${ }^{22}$ MORAES, José Geraldo Vinci de. Cidade e cultura urbana na Primeira República. São Paulo: Atual, 1994, pp. 44-65.

${ }^{23}$ Para maiores esclarecimentos ver: a) BRESCIANI, Maria Stella Martins. História e Historiografia das Cidades: um percurso. In: FREITAS, Marcos Cezar. (Org.). Historiografia brasileira em perspectiva. São Paulo: Contexto, 1998, pp. 237258; b) ___. A Cidade: objeto de estudo e experiência vivenciada. Revista Brasileira de Estudos Urbanos e Regionais. São Paulo: ANPUR, v. 6, n. 2, pp. 9-26, nov. 2004; c) ___. Melhoramentos entre intervenções e projetos estéticos: São Paulo (1850-1950). In: BRESCIANI, Maria Stella M. (Org.). Palavras da cidade. Porto Alegre: UFRGS, 2001, pp. 343-366; d) CAMPOS, Cândido M. Os Rumos da Cidade: Urbanismo e Modernização em São Paulo. São Paulo: Senac, 2002; e) SÁVIO, Marco Antônio Cornacioni. A Modernidade sobre Rodas. São Paulo: EDUC, 2002.
} 
governo federal de Rodrigues Alves (1902-1906), que colocara à frente da prefeitura o engenheiro Francisco Pereira Passos, o qual partilhava com Antônio Prado a ligação com os setores progressistas do governo republicano ${ }^{24}$.

Para o caso da cidade de São Paulo, o secretário de obras Victor Freire, citado por Maria Stella Martins Bresciani, observa, em 1914, não haver dúvidas quanto aos benefícios da (FREIRE (1914) apud BRESCIANNI, 1996) “[...] influência que a luz e o ar assumem na salubridade das aglomerações humanas [...]”. Assim, em sua opinião, assegurar o bom funcionamento do ar e dos raios solares constituía a melhor técnica para combater doenças como a tuberculose e a febre amarela ${ }^{25}$. As autoridades procuravam, também, excluir do centro da cidade as populações cujo estado extremo de miséria as forçavam a aglutinarem-se em casebres às margens da Várzea do Carmo e da Baixada do Piques. Esses eram núcleos paulistanos com forte presença de negros, resultantes de grupos de escravos evadidos das lavouras de café. As iniciativas governamentais objetivavam apenas a evacuação dessas populações, equiparadas em linguagem discricionária agressiva aos estigmas dos insetos, da sujeira, da doença e do crime, sem fazer qualquer menção à sua realocação ou a seu destino ${ }^{26}$.

Entendemos que as mudanças e alterações urbanas verificadas no período, nos principais centros urbanos do país, entraram em choque com visões e tendências políticas diversas que, em inúmeros momentos e ocasiões, salientaram a complexidade e a diversidade das propostas urbanísticas locais. Elas envolveram, portanto, diferentes posturas, divergências teóricas e distintas filiações e a forma como se procurou adequá-las às limitações impostas pelas condicionantes paisagísticas e político-urbanas de cada localidade.

Nesse sentido, o livro Os Rumos da Cidade: Urbanismo e Modernização em São Paulo (São Paulo: Senac, 2002), do arquiteto Cândido Malta Campos, surge como uma importante contribuição para a compreensão do papel de urbanistas e políticos nas transformações do espaço dessa cidade, no período entre os anos de 1870 e 1945. Produzido como tese de doutorado pelo programa de Pós-Graduação da Faculdade de Arquitetura e Urbanismo da USP, trata-se de um estudo abrangente que recupera e articula aspectos relevantes das transformações pelas quais passou a cidade de São Paulo - especialmente sua área central ao longo do período em análise.

\footnotetext{
${ }^{24}$ CAMPOS, Cândido Malta. Os Rumos da Cidade: Urbanismo e Modernização em São Paulo. São Paulo: Senac, 2002.

${ }^{25}$ BRESCIANNI, Maria Stella Martins. Imagens de São Paulo: Estética e Cidadania. In: Anais do IV Seminário de História da Cidade e do Urbanismo. Rio de Janeiro, v. 1, pp. 465-474, nov. 1996.

${ }^{26}$ SEVCENKO, Nicolau. Orfeu extático na metrópole: São Paulo, sociedade e cultura nos frementes anos 20. São Paulo: Companhia das Letras, 1992, pp. 140-141.
} 
O autor investiga a gestação e o conteúdo de projetos urbanísticos e de instrumentos intervencionistas ou reguladores do espaço urbano da capital paulista, como códigos de obras e de zoneamentos, normas de parcelamento, taxas de melhoria etc. Por outro lado, o autor salienta o papel relevante desempenhado por engenheiros, arquitetos, urbanistas e figuras políticas nacionais e paulistanas perante as transformações urbanas verificadas para a cidade de São Paulo, durante as décadas de 1920 e 1930, e às naturais disputas políticas empreendidas para sua efetivação. Dentre esses personagens, destacamos Victor Freire, Saturnino de Brito, Artur Sabóia, Alexandre de Albuquerque, Anhaia Melo e Prestes Maia. O grande mérito de sua obra é, todavia, desvendar aspectos desses embates. O autor sinaliza como essas disputas políticas envolvem demandas simbólicas, estéticas, higienistas, de valorização imobiliária e interesses políticos e comerciais ${ }^{27}$.

Outra questão enfatizada refere-se às diferentes formas de apropriação e à assimilação de experiências e de modelos internacionais. A esse respeito, destacamos que, nas primeiras décadas do século XX, modelos de inspiração "haussmanniana” - então privilegiados nas intervenções urbanísticas nas capitais nacionais - chocaram-se com padrões de inspiração “sittiana”, defendidos por urbanistas como Victor Freire e Saturnino de Brito (1864-1929), personagens que simpatizavam com a aplicação de soluções urbanísticas adequadas às situações locais e atentas às particularidades do sítio urbano; avessos, portanto, à aplicação de modelos urbanísticos arbitrários. Cândido Malta Campos demonstra, também, como a ênfase das propostas urbanísticas foi deslocando-se de questões sanitárias para preocupações viárias, num movimento que redefine os padrões estéticos eleitos e sua aplicação nos planos urbanísticos, pois segundo Campos (2002, p. 11) “[...] a São Paulo dos bulevares [...]” e o “[...] estilo neocolonial terão sua época até a chegada dos anos 1920, com as discussões sobre urbanidade e modernismo [...]”. Assim, ao assinalar o descompasso entre planos e intervenções, o autor sinaliza os limites dos projetos teóricos quando das tentativas de sua aplicação prática no espaço urbano de São Paulo.

O eixo central da obra é, portanto, analisar precisamente o vasto campo de lutas que permeia o pensamento e a prática do urbanismo. Em outras palavras, podemos considerar que os processos de higienização e de disciplinarização urbana eram efetuados de maneira parcial e excludente, pois atendiam a interesses políticos específicos, relacionados à especulação urbana; ou encontravam resistência perante as correntes políticas desfavoráveis ou mesmo às necessidades e aos comportamentos dos habitantes da urbe. Assim, a coerência e o alcance

\footnotetext{
${ }^{27}$ CORREIA, Telma de Barros. Os Rumos da Cidade: Urbanismo e Modernização em São Paulo. Resenha. São Paulo: Senac, 2002. Revista Brasileira de Estudos Urbanos e Regionais. São Paulo: ANPUR, n. 5, p. 119, maio 2002.
} 
das propostas urbanísticas elaboradas para as cidades brasileiras eram limitados, e a situação apresentada pela capital paulista aponta, ao que parece, uma primeira diferença fundamental, pois conforme Campos (2002, p. 67), “[...] ao contrário das cidades de Paris ou Rio de Janeiro, onde os arquitetos se formavam nas Escolas de Belas-Artes, o ensino da arquitetura em São Paulo passou a ser uma especialidade da engenharia [...]” 28.

Oferecemos, a seguir, um exemplo dos embates e conflitos envolvidos em torno de projetos de reformulação urbana da cidade de São Paulo. Os inúmeros projetos arquitetônicos e paisagísticos propostos para a capital paulista, entre o final do século XIX e, pelo menos, até a década de 1920 - dentre eles, a construção e inauguração do Viaduto do Chá (1898) e a construção e inauguração da Avenida Paulista (inaugurada por volta de 1896) - salientam disputas políticas e posicionamentos divergentes sobre os rumos e direções que tais projetos deveriam assumir. Para termos uma ideia mais aproximada sobre essas disputas, podemos observar, o que o então diretor de Obras Municipais de São Paulo, Victor Freire, afirma na Conferência intitulada Os melhoramentos de São Paulo, proferida no Grêmio Politécnico, em 15 de fevereiro de 1911. Nessa ocasião, Freire, citado por Cândido M. Campos, considera que

[...] o paradigma haussmanniano deveria ser superado [...], pois [a] origem dessa falsa noção vem da transformação de Paris [...] pelo barão Haussmann [...]. O público bateu palmas e o exemplo passou as fronteiras. Porém, 'seria um erro acreditar que os processos empregados em Paris [...] produziriam mais efeitos em outros lugares'. Para resolver aspectos técnicos e estéticos da remodelação de São Paulo, deveriam ser adotados os princípios do urbanismo científico exemplificado nos ensinamentos de $\mathrm{Sitte}^{29}$. O terreno acidentado, a situação do centro urbano sobre uma colina a cavaleiro de dois vales, as linhas de penetração para os bairros, tudo leva à adoção dos traçados não ortogonais, e sugeria o pitoresco como recurso de valorização paisagística: 'não é precisamente a curva que melhor se presta [...] à configuração do novo terreno acidentado, do qual suga a cidade o seu elemento característico de encanto: o pitoresco?' (FREIRE (1911) apud CAMPOS, 2002, p. 128).

Corroborando com essas explanações, destacamos que Victor Freire, na conferência intitulada A cidade Salubre, proferida também no Grêmio Politécnico, em março de 1914 citado por Cândido Malta Campos,

\footnotetext{
${ }^{28}$ A esse propósito, temos que o Instituto e a Escola Politécnica do Estado de São Paulo foram fundados, respectivamente, nos anos de 1892 e 1893. Ver, a respeito, CAMPOS, Cândido Malta. Os Rumos da Cidade: Urbanismo e Modernização em São Paulo... op. cit., p. 64.

${ }^{29}$ Camillo Sitte (1843-1903). Arquiteto e historiador da arte, diretor da Escola Imperial e Real de Artes Industriais de Viena, foi o autor do estudo urbanístico Construção das Cidades Segundo seus Princípios Artísticos ("Der Städtebau nach seinen künstlerischen Grundsätzen”). Nesse estudo, Sitte opera uma análise das cidades na história e propõe a reavalização dos meios urbanos através de seus espaços existentes, principalmente suas praças e parques. Nesse sentido, é possível considerarmos que o seu objetivo foi polemizar contra as transformações de Viena e o planejamento do Ringstrasse, segundo princípios do Barão Georges-Eugène Haussmann. Sua obra foi, também, fonte de inspiração para Patrick Geddes e Lewis Mumford.
} 
Considerava exagerado o padrão da rua reta de 16 metros de largura, adotado pelo Código de Posturas paulistano de 1886. Seria uma transposição indevida de normas francesas, compatível apenas com o padrão de ocupação residencial centro-europeu, com seus quarteirões compactos, lotes quadrados e blocos de apartamentos com grandes pátios internos. Freire pretendia, então, que as práticas anglo-saxônicas de arruamento (ruas locais mais estreitas), parcelamento (lotes uni familiares) e ocupação (maior proporção de terreno livre) fossem adotadas no caso paulistano, possibilitando economia de área ocupada pelo sistema viário, em benefício de espaços livres no interior das quadras e de pequenos parques nos bairros residenciais (FREIRE (1914), apud, CAMPOS, 2002, p. 131).

Analisando as ideias citadas, devemos esclarecer, em primeira mão, que, em suas conferências, Freire apresentou exemplos retirados da obra de Sitte e das realizações do urbanismo sittiano alemão da virada do século. Nesse sentido, buscava argumentos para desbancar a imagem do bulevar retilíneo e uniforme à parisiense, pois todos os projetos, apresentados até então para a capital paulista, procuravam, sem sucesso, encaixar uma “avenida central” na difícil topografia da cidade $^{30}$. O diretor de Obras atacava, assim, os projetos de Samuel das Neves e Alexandre de Albuquerque ${ }^{31}$, baseados no princípio, por ele considerado, ultrapassado e antiestético dos alinhamentos em linha reta ${ }^{32}$.

As ideias destacadas, nessas citações, também se referem às críticas às (FREIRE (1911), apud, CAMPOS, 2002, p. 128) “[...] 'versões descontextualizadas das realizações de Haussmann' [...]”, qualificando-as de “[...] 'horrores [...] impecáveis, aliás, quanto ao alinhamento - como a Avenida Central do Rio’ [...]”. Desse modo, destacamos a preocupação com a irregularidade cuidadosamente controlada, a variedade volumétrio-espacial e a recusa da monotonia ortogonal; elementos estes que ilustravam uma postura crítica em relação aos alinhamentos retilíneos, aos efeitos de perspectiva e às edificações uniformes, presentes no modelo parisiense e sonhado pelas elites locais ${ }^{33}$.

\footnotetext{
${ }^{30}$ FREIRE, Victor da Silva. Os melhoramentos de São Paulo. Conferência no Grêmio Politécnico, 15 fev. 1911, pp. 101-104 apud CAMPOS, Cândido Malta. Os Rumos da Cidade: Urbanismo e Modernização em São Paulo... op. cit., p. 128.

${ }^{31}$ Alexandre de Albuquerque, por exemplo, era engenheiro civil e arquiteto formado pela Escola Politécnica em 1905; e a partir de 1909, trouxe da Europa um vasto repertório artístico e arquitetônico, que o tornava qualificado a subscrever um projeto que visava à "haussmannização" de São Paulo. Nesse contexto, em novembro de 1910, um conjunto de notáveis endereçou ao Congresso Legislativo do Estado, petição solicitando apoio oficial para um projeto de urbanização destinado a transformar o quadrante Oeste de São Paulo em novo espaço central, com desenho monumental e caráter europeu. O grupo era formado por alguns dos maiores representantes da elite política e econômica paulistana, incluindo Plínio da Silva Prado, filho de Martinho Prado Júnior e sobrinho do prefeito Antônio Prado; José Paulino Nogueira, fazendeiro e chefe político da região entre Campinas e Limeira; José Martiniano Rodrigues Alves, dentre outros. O projeto de Alexandre de Albuquerque ficou conhecido como o das "grandes avenidas", pois era baseado na superposição de novos eixos viários sobre o tecido urbano existente, a partir do qual três vias largas e retas cortariam os bairros do Morro do Chá e Santa Ifigênia. A principal delas iria da Praça Antônio Prado à chácara do Carvalho; outra ligaria o Teatro Municipal e o Viaduto do Chá às estações da Luz e Sorocabana; e uma terceira partiria do Largo de Santa Ifigênia rumo ao Arouche e Higienópolis. (CAMPOS, Cândido Malta. Os Rumos da Cidade: Urbanismo e Modernização em São Paulo... op. cit., pp. 115-117).

${ }^{32}$ CAMPOS, Cândido Malta. Os Rumos da Cidade: Urbanismo e Modernização em São Paulo... op. cit., p. 128.

${ }^{33}$ Idem.
} 
Outro aspecto que destacamos é o fato de que os trabalhos relativos à remodelação do espaço central da cidade do Rio de Janeiro, empreendidos, especialmente, durante o início do século XX, serviram de inspiração para a modernização urbana buscada pelos setores dominantes em várias cidades e capitais brasileiras. Segundo Campos (2002, p. 139), esses espaços “[...] almejavam possuir sua pequena 'Étoile’ [...]”; “[...] ter a sua 'avenida central' [...]”, e, desse modo, não era apenas a inadequação desse modelo para a situação paulistana que estava em jogo nos argumentos de Victor Freire, mas a necessidade de superar tal paradigma e construir outro, mais autônomo - que estabelecesse para a cidade de São Paulo um caminho próprio, não mais subordinado à capital federal.

É importante considerarmos que, para os efeitos deste estudo, a elaboração e a implementação de projetos de cunho urbanístico para a cidade de São Paulo, especialmente durante o final do século XIX e as três primeiras décadas do século XX, suscitaram discussões e embates em torno de um ou mais pontos de vista, o que colocou, lado a lado, posicionamentos ideológicos, muitas vezes, divergentes sobre determinado assunto ou decisão. Sem dúvida, essa situação é aplicável aos demais contextos urbanos brasileiros do período. Não nos cabe, neste espaço, tecer uma discussão aprofundada sobre os meandros das disputas políticas que envolviam a implementação de projetos urbano-paisagísticos para os principais centros urbanos do país. Entendemos, todavia, que as ideias destacadas anteriormente oferecem um parâmetro sobre a complexidade que envolvia a adoção de posturas ou medidas práticas para a higienização ou reformulação urbana dos principais centros urbanos brasileiros.

As tentativas de reformulação e modernização das principais cidades do país são levadas a cabo, sobretudo, no período republicano, especialmente durante a chamada República Velha (1889-1930), pois os grupos políticos e ideológicos que o fundamentaram ligados à forte orientação positivista e avessos ou não alinhados ao pretenso imobilismo imperial e escravagista - simpatizavam com o progresso material e moral da sociedade brasileira da época. Essa ordem de ideias saturou, portanto, o ambiente intelectual do país nas décadas seguintes e emprestou suporte ideológico para a ação "saneadora” dos engenheiros e médicos, que passaram a encastelar-se e acumular poder na administração pública, especialmente após o golpe militar republicano de $1889^{34}$.

Desse modo, a partir da década de 1870, os higienistas passaram a defender, de maneira mais intransigente, a ideia de que era preciso intervir no ambiente urbano com o intuito de

\footnotetext{
${ }^{34}$ Para uma discussão mais aprofundada, ver CARVALHO, José Murilo de. A formação das almas: o imaginário da República no Brasil. São Paulo: Companhia das Letras, 1990.
} 
controlar doenças e males infecciosos; entretanto, a linguagem por eles utilizada assumiu, todavia, gradativamente, claros significados políticos e discriminatórios raciais. Nesse sentido, a aliança entre as ações políticas e higienistas foi a principal estratégia adotada pelas elites brasileiras - dirigentes dos principais centros urbanos do país - para coordenar ações no sentido de sanear e prover a higienização de comportamentos sociais e espaços urbanos ${ }^{35}$.

Aprofundando essa discussão, dentre outros estudos que discutem as questões sanitárias e a higienização de espaços urbanos e comportamentos sociais, destacamos o texto de Sidney Chalhoub: Cidade Febril: cortiços e epidemias na Corte Imperial (São Paulo: Companhia das Letras, 1996). Esse estudo é direcionado sob a perspectiva da História Social e enfoca debates sobre o que o autor chama de "ideologia da higienização", que permeou as ações políticas e médicohigienistas durante o final do século XIX e o início do século passado, direcionadas para a "limpeza” e a “desodorização” dos cortiços cariocas; sobre o combate à febre amarela e, em sua esteira, às populações negras e pobres dos arrabaldes e morros do Rio; e também sobre as campanhas em prol da aplicação da vacina antivariólica etc. Assim, segundo Chalhoub (1996, p. 08), era preciso, “[...] dizia-se, intervir radicalmente na cidade para eliminar tais habitações coletivas e afastar do centro da Capital as ‘classes perigosas' que nele residiam; classes duplamente perigosas, porque propagavam a doença e desafiavam as políticas de controle social no meio urbano”.

Nesse contexto, Sidney Chalhoub considera que se configura uma oposição entre “civilização” e "tempos coloniais”, princípios essenciais para a compreensão de um imaginário em gestação entre os políticos e governantes, nas últimas décadas do século passado. Em primeiro lugar, está presente a ideia de que existe um "caminho da civilização”, isto é, um modelo de aperfeiçoamento social e moral. Esse processo configurou os pressupostos da Higiene como um conjunto de princípios que conduziriam o País ao “verdadeiro”, à “civilização”, e que implicaram na legitimação apriorística das decisões quanto às políticas públicas a serem aplicadas no meio urbano ${ }^{36}$.

Mas os motivos para o surgimento de uma crise sanitária nos grandes centros urbanos do país - especialmente nas cidades do Rio de Janeiro e São Paulo - não esclarecem as razões pelas quais a saúde pública manifestou-se como uma questão urgente em Florianópolis no mesmo período; pois, no decorrer daqueles anos, a capital catarinense continuou em seu ritmo

\footnotetext{
${ }^{35}$ Observar a respeito: a) HERSCHMANN, Micael M; PEREIRA, Carlos Alberto M. O imaginário moderno no Brasil. In: . (Org.). A invenção do Brasil Moderno: medicina, educação e engenharia nos anos 20 e 30. Rio de Janeiro: Rocco, 1994; e b) GONDRA, José G. Medicina, Higiene e Educação Escolar. In: LOPES, Eliane Marta Teixeira; FILHO, Luciano Mendes Faria; VEIGA, Cynthia Greive. (Org). 500 anos de educação no Brasil. 3. ed. Belo Horizonte: Autêntica, 2003.

${ }^{36}$ CHALHOUB, Sidney. Cidade Febril: cortiços e epidemias na Corte Imperial. São Paulo: Companhia das Letras, 1996, p. 35.
} 
pacato. Ela não apresentou afluxos populacionais significativos e sua estrutura urbana pouco havia mudado desde o final do século XIX. Além disso, desde 1910, ocorria uma progressiva melhoria dos aspectos sanitário e urbano, como decorrência da instalação das redes de água e esgotos e da primeira rede de iluminação elétrica. Em suma, na pequena Florianópolis, poucas características pareciam adequar-se às causas que desencadearam os problemas urbanos e sanitários verificados nas grandes cidades brasileiras, no início do século.

Durante as décadas de 1910 e 1920, a cidade foi, porém, palco de uma série de intervenções na sua área central que, em nome da necessidade de reformas urbanas e sanitárias, prescreveram e introduziram novas regras de convívio urbano. Assim, ruas foram calçadas, ajardinaram-se praças, foi instalada uma rede de energia elétrica, e, alguns edifícios públicos foram construídos e reformados. Acompanhando as mudanças que se operavam na paisagem da cidade, passou-se a normatizar e a classificar algumas atitudes cotidianas, como jogar ou lançar materiais fecais, lixo e entulhos nos quintais, praças e ruas do perímetro da cidade e povoações; pendurar roupas e gaiolas nas janelas e fachadas das casas; criar galinhas e outros animais; e manifestar palavras obscenas ou licenciosas que ofendessem a moralidade pública, como práticas não condizentes com a vida de uma Capital $^{37}$.

Em face às suas dimensões populacional, predial e urbanística, podemos considerar que Florianópolis, apesar de não ser uma cidade moderna como São Paulo ou Rio de Janeiro, era considerada como tal nos discursos da imprensa e do governo. Salientamos, pois, que a capital catarinense não pode ser considerada uma cidade moderna a exemplo dos grandes centros urbanos brasileiros; e, especialmente, se comparada às grandes cidades europeias, sobretudo Paris e Londres, pois as iniciativas governamentais e as transformações urbanas assumiram, aqui, muito menor envergadura.

Dado o exposto, como podemos explicar a posição da imprensa e dos órgãos governamentais da época? Entendemos que a explicação mais apropriada consubstancia-se na ideia de representação que, segundo Le Goff (1985), “[...] é a tradução mental de uma realidade exterior percebida e liga-se ao processo de abstração [...]”. Nesse sentido, conforme Sandra Jatahy Pesavento (1995, p. 15), o “[...] imaginário faz parte de um campo de representações e, como expressão do pensamento, se manifesta por imagens e discursos que pretendem dar uma definição de realidade [...]”. Destacamos, entretanto, que (PESAVENTO,

\footnotetext{
${ }^{37}$ DESTERRO. Câmara Municipal da Cidade do Desterro. Código de Posturas. Lei 1238, de 22 de outubro de 1888. Desterro: Tipografia da Regeneração, 1889, p. 14 e p. 25; ARAÚJO, Hermetes Reis de. Fronteiras internas: urbanização e saúde pública em Florianópolis nos anos 20... op. cit., p. 107.
} 
1995, p. 15) “[...] imagens e discursos sobre o real não são exatamente o real ou, em outras palavras, não são expressões literais da realidade [...]”. Esse processo envolve, portanto,

[...] a relação que se estabelece entre significantes (imagens, palavras) com os seus significados (representações, significações), processo este que envolve uma dimensão simbólica; [e nessa articulação], [...] a sociedade constrói a sua ordem simbólica, que, se por um lado não é o que se convenciona chamar de real (mas sim de sua representação), por outro lado é também uma outra forma de existência da realidade histórica (PESAVENTO, 1995, p. 16) ${ }^{38}$.

A partir dessas explanações, podemos afirmar que Florianópolis, apesar de não ser uma cidade moderna, como São Paulo ou Rio de Janeiro, era considerada como tal nos discursos da imprensa e do governo. Assim, a representação imaginária da cidade moderna ganhava força de realidade, pois (Saneamento de Florianópolis. República, 1919, p. 1) “[...] aqui e ali, ainda se contorcem vilas de aspecto colonial ladeadas de casas quadradas e incompatíveis a uma cidade moderna que se quer salubre e confortável [...]”. Em vista disso, os discursos proferidos por engenheiros, autoridades governamentais e pela imprensa procuraram perpetuar a ideia de que Florianópolis era uma cidade moderna, pois comportamentos e valores considerados incivilizados e imorais foram coibidos e as reformas urbanas eram salientadas constantemente.

Os estudos sobre a modernidade nas cidades do Rio de Janeiro, São Paulo e Florianópolis salientam aspectos similares. Dentre eles, destacam-se o saneamento e a higienização do centro da cidade, pois intervenções governamentais variadas configuraram estratégias sanitárias fundamentadas na eliminação dos focos de doenças e de comportamentos inadequados na área central. Outro elemento importante diz respeito às tentativas de se afastar, progressivamente, as populações mais desfavorecidas do centro da cidade. Configura-se, assim, um gradual processo de homogeneização social e paisagística do espaço físico central ${ }^{39}$ - que é operado de maneira lenta e conflituosa, com todas as circunstâncias e especificidades políticas, sociais e sanitárias nele envolvidas.

\footnotetext{
${ }^{38}$ Ver, também, da mesma autora, outro texto que trabalha sob essa perspectiva: PESAVENTO, Sandra Jatahy. Cidades visíveis; cidades sensíveis, cidades imaginárias. Revista Brasileira de História. São Paulo, v. 27, n. 53, jan./jun. 2007.

${ }^{39}$ Ver: SENNET, Richard. O declínio do homem público: as tiranias da intimidade. São Paulo: Companhia das Letras, 1998, p. 361.
} 


\title{
FLORIANOPOLIS: urban space, public power and discipline (the 1910s and 1920s)
}

\begin{abstract}
This article aims to discuss improvements in the legal apparatus introduced in Santa Catarina and its capital, especially during the 1910s and 1920s. This apparatus had the aim of better organizing and controlling the mobility of vehicles - motorized and/or driven by animals - on roads between municipalities and on the streets of the urban perimeter of Florianopolis. We also analyze the perceptions expressed by local government agencies of efforts to provide sanitation within the urban boundary of the state capital. These disciplinary actions sought to adapt the space to the civilizing attitudes propagated by local elites, as observed in factions associated with Republican points of view, who aspired - at least in theory - to the material and moral progress of Brazilian society at that time.
\end{abstract}

Keywords: Disciplining. Social Behaviors. Municipality. Sanitation; Hygiene. 


\section{Referências:}

ARAÚJO, Hermetes Reis de. A invenção do litoral: Reformas urbanas e reajustamento social em Florianópolis na Primeira República. Dissertação (Mestrado em História). São Paulo: PUC, 1989.

Fronteiras Internas: Urbanização e Saúde Pública em Florianópolis nos anos 20. In: BRANCHER, Ana (Org.). História de Santa Catarina: estudos contemporâneos. Florianópolis: Letras Contemporâneas, 1999, pp. 102-113.

BRESCIANNI, Maria Stella Martins. Imagens de São Paulo: Estética e Cidadania. In: Anais do IV Seminário de História da Cidade e do Urbanismo. Rio de Janeiro, v. 1, p. 465-474, nov. 1996.

História e Historiografia das Cidades: um percurso. In: FREITAS, Marcos Cezar. (Org.). Historiografia brasileira em perspectiva. São Paulo: Contexto, 1998, pp. 237-258.

Melhoramentos entre intervenções e projetos estéticos: São Paulo (1850-1950). In: BRESCIANI, Maria Stella M. (Org.). Palavras da cidade. Porto Alegre: UFRGS, 2001, pp. 343-366.

A Cidade: objeto de estudo e experiência vivenciada. Revista Brasileira de Estudos Urbanos e Regionais. São Paulo: ANPUR, v. 6, n. 2, pp. 9-26, nov. 2004.

CAMPOS, C. M. Os Rumos da Cidade: Urbanismo e Modernização em São Paulo. São Paulo: Senac, 2002.

CARVALHO, José Murilo de. A formação das almas: o imaginário da República no Brasil. São Paulo: Companhia das Letras, 1990.

CHALHOUB, Sidney. Cidade Febril: cortiços e epidemias na Corte Imperial. São Paulo: Cia. das Letras, 1996.

CORREIA, Telma de Barros. Os Rumos da Cidade: Urbanismo e Modernização em São Paulo. Resenha. São Paulo: Senac, 2002. Revista Brasileira de Estudos Urbanos e Regionais. São Paulo: ANPUR, n. 5, maio 2002.

DESTERRO. Câmara Municipal da Cidade do Desterro. Código de Posturas. Lei 1238, de 22 de outubro de 1888. Desterro: Tipografia da Regeneração, 1889.

DESTERRO. THIAGO, Polidoro Olavo de São. Ofício encaminhado ao Presidente da Província João Rodrigues Chaves. Desterro, 03 nov. 1880.

FLORIANÓPOLIS. Código de Posturas Municipais de Florianópolis. Florianópolis: Tip. da República, 1896.

GONDRA, José G. Medicina, Higiene e Educação Escolar. In: LOPES, Eliane Marta Teixeira; FILHO, Luciano Mendes Faria; VEIGA, Cynthia Greive. (Org). 500 anos de educação no Brasil. 3. ed. Belo Horizonte: Autêntica, 2003. 
HERSCHMANN, Micael M; PEREIRA, Carlos Alberto M. O imaginário moderno no Brasil. In: _. (Org.). A invenção do Brasil Moderno: medicina, educação e engenharia nos anos 20 e 30. Rio de Janeiro: Rocco, 1994.

IBGE. Anuário Estatístico do Brasil, Rio de Janeiro, 1999, v. 59.

LE GOFF, Jacques. L’imaginaire médiéval. Paris: Gallimard, 1985.

MEIRINHO, Jali. República e Oligarquias: subsídios para a história catarinense - 1889_ 1930. Florianópolis: Insular, 1997.

MORAES, José Geraldo Vinci de. Cidade e cultura urbana na Primeira República. São Paulo: Atual, 1994.

Os bondes de Florianópolis. O Estado, Florianópolis, 10 jan., 1925, p. 5.

PESAVENTO, Sandra Jatahy. Em busca de uma outra história: imaginando o imaginário. Revista Brasileira de História. São Paulo: ANPUH/Contexto, v. 15, n. 29, p. 15, 1995.

Cidades visíveis; cidades sensíveis, cidades imaginárias. Revista Brasileira de História. São Paulo, v. 27, n. 53, jan./jun. 2007.

Processo 194, de 21 de novembro de 1932, Caixa 20.

Remodelação de Florianópolis. República, Florianópolis, 1. ㅇ fev., 1920, p. 1.

Saneamento de Florianópolis. República, Florianópolis, 08 set., 1919, p. 1.

SANTA CATARINA. Lei 111 , de $1 .^{\circ}$ de outubro de 1894 . Altera o nome da cidade do Desterro para Florianópolis. Florianópolis, 1894.

SANTA CATARINA. Decreto 846, de 29 de dezembro de 1914. In: Leis, Decretos, Resoluções e Portarias de 1914. Florianópolis: Gab. Tipografia d’ O Dia, 1915.

SANTA CATARINA. Decreto 1116, de 10 de abril de 1918. Aprovando o regulamento para as estradas de rodagem estaduais. In: Colecção de Leis, Decretos e Resoluções de 1918. Florianópolis: Imprensa Oficial, 1919.

SANTA CATARINA. Lei 1325, de 18 de agosto de 1920. Dispondo sobre o exame de habilitação para condutores de automóveis. In: Coleção de Leis, Decretos, Resoluções e Portarias de 1920. Florianópolis: Imprensa Oficial, 1920.

SANTA CATARINA. Decreto 1465A, de 17 de maio de 1921. Criando, na Força Pública, uma seção para serviços especiais de automóveis. In: Coleção de Leis, Decretos e Resoluções de 1921. Florianópolis: Imprensa Oficial, 1921.

SANTA CATARINA. OLIVEIRA, Antônio Pereira da Silva. Superintendente Municipal. MENSAGEM dirigida ao Conselho Municipal em $1^{\circ}$ de abril. Florianópolis, Gazeta Oficial, 15 abr. 1905. 
SANTA CATARINA. LUZ, Hercílio Pedro da. Vice-Governador, no exercício do cargo de Governador do Estado de Santa Catarina. MENSAGEM apresentada ao Congresso Representativo. Florianópolis, 22 jul. 1919.

SANTA CATARINA. Regulamento das estradas estaduais e respectivo imposto de trânsito a que se refere o Decreto 846, de 29 de dezembro de 1914. In: Leis, Decretos, Resoluções e Portarias de 1914. Florianópolis: Gab. Tipografia d’ O Dia, 1915.

SANTA CATARINA. Regulamento para as estradas estaduais a que se refere o Decreto 1116 desta data. In: O Dia. Florianópolis, 16 e 17 abr. 1918.

SANTA CATARINA. Regulamento para o serviço policial do Estado. Florianópolis: Tipografia da Livraria Central, 1920.

SANTA CATARINA. Instruções Regulamentares para o serviço de trânsito público. Florianópolis: Imprensa Oficial, 1928.

SANTA CATARINA. RIBEIRO, João Alberto Miranda. Ofícios recebidos pela Câmara do Governador João Alberto Miranda Ribeiro. Desterro, 26 jun. 1794.

SANTA CATARINA. COUTINHO, João José. Relatório apresentado à Assembleia Provincial de Santa Catarina. Desterro, 19 abr. 1854.

SANTA CATARINA. ROCHA, Francisco José da. Relatório apresentado à Assembleia Legislativa Provincial de Santa Catarina. Rio de Janeiro, 1888.

SANTA CATARINA. Relatório Apresentado ao Exmo. Sr. Coronel Vidal José de Oliveira Ramos, digníssimo Governador do Estado pelo Desembargador Sílvio de Sá Gonzaga, Chefe de Polícia, em 1. e junho de 1911. Florianópolis: Gab. Tip. d’ O Dia, 1911.

SANTA CATARINA. Relatório Apresentado ao Exmo. Sr. Secretário Geral do Estado pelo Chefe de Polícia Ulysses Gerson Alves da Costa. Florianópolis, 14 maio de 1915.

SANTA CATARINA. Relatório Apresentado ao Exmo. Sr. Dr. Joë Luiz M. Colaço, Secretário do Interior e Justiça pelo Desembargador Antero de Assis, Chefe de Polícia. Florianópolis, 1922.

SANTA CATARINA. Relatório da Chefatura de Polícia Apresentado ao Exmo. Sr. Dr. Secretário do Interior e Justiça. Florianópolis, 1929.

SÁVIO, Marco Antônio Cornacioni. A Modernidade sobre Rodas. São Paulo: EDUC, 2002.

SENNET, R. O declínio do homem público: as tiranias da intimidade. São Paulo: Companhia das Letras, 1998.

SEVCENKO, Nicolau. Orfeu extático na metrópole: São Paulo, sociedade e cultura nos frementes anos 20. São Paulo: Companhia das Letras, 1992. 
A capital irradiante: técnica, ritmos e ritos do rio. In: . (Org.). História da vida privada no Brasil - República: da Belle Époque à Era do Rádio. 5. ed. São Paulo: Companhia das Letras, 2002, pp. 513-619.

Um bonde destruído por populares. O Estado, Florianópolis, 26 set., 1934, p. 6.

VEIGA, Eliane V. da. Florianópolis: memória urbana. Florianópolis: UFSC/Fundação Franklin Cascaes, 1993. 